\title{
Lacustrine mollusc radiations in the Lake Malawi Basin: experiments in a natural laboratory for evolution
}

\author{
D. Van Damme and A. Gautier \\ Paleontological Research Unit, Ghent University, Krijgslaan 281, 9000, Gent, Belgium \\ Correspondence to: D. Van Damme (dirk.vandamme@ugent.be) \\ Received: 17 July 2012 - Published in Biogeosciences Discuss.: 18 December 2012 \\ Revised: 25 July 2013 - Accepted: 25 July 2013 - Published: 3 September 2013
}

\begin{abstract}
In terminal Pliocene-early Pleistocene times, part of the Malawi Basin was occupied by paleo-lake Chiwondo. Molluscan biostratigraphy situates this freshwater lake either in the East African wet phase between 2.7-2.4 Ma or that of 2.0-1.8 Ma. In-lake divergent evolution remained restricted to a few molluscan taxa and was very modest. The lacustrine Chiwondo fauna went extinct at the beginning of the Pleistocene. The modern Lake Malawi malacofauna is depauperate and descends from ubiquistic southeast African taxa and some Malawi basin endemics that invaded the present lake after the Late Pleistocene mega-droughts. The Pleistocene aridity crises caused dramatic changes, affecting the malacofauna of all East African lakes. All lacustrine endemic faunas that had evolved in the Pliocene rift lakes, such as paleo-lake Chiwondo, became extinct. In Lake Tanganyika, the freshwater ecosystem did not crash as in other lakes, but the environmental changes were sufficiently important to trigger a vast radiation. All African endemic lacustrine molluscan clades that are the result of in-lake divergence are hence geologically young, including the vast Lavigeria clade in Lake Tanganyika (ca. 43 species).
\end{abstract}

\section{Introduction}

The hypothesis that the large African lakes are "natural laboratories of evolution" and that their diversified molluscan fauna are prime examples of intense and ancient processes of in-lake evolution (Michel et al., 1991) has become generally accepted. The recent and fossil malacofauna of Lake Malawi does not corroborate this theory. In fact, all actual molecular and paleontological investigations provide evidence pointing to the contrary, namely that in Lake Malawi, as well as in other past and present rift lakes, molluscan in-lake divergence is surprisingly modest and young geologically speaking. This view is partly applicable even to the unique malacofauna of Lake Tanganyika. The present study links the late origin of the malacofaunas of the present rift lakes to the increasing climate destabilisation in East Africa since the late Pliocene.

\section{The fossil record}

This study is based on the collections of terminal Plioceneearly Pleistocene molluscs collected in the Chiwondo region (NW margin of Lake Malawi), respectively, in the 1960s during the Desmond Clark Palaeo-Antropological Investigation and in 1980-1990s during the Hominid Corridor Research Project led by Timothy Bromage and Friedemann Schrenk. Albrecht Gorthner, the HCRP malacologist, also sampled the Holocene assemblages near the Shire River outlet and this preliminary investigation was recently continued (Van Bocxlaer, 2004; Van Bocxlaer et al., 2012). All relevant fossil material collected in the Malawi Basin is provisionally stored at the Paleontological Research Unit, Ghent University, awaiting formal taxonomic description. The taxonomy of the Desmond Clark collection was studied by Gautier (A. Gautier, unpublished data, 1968) and taxonomy and biostratigraphy of the HCRP-collection by A. Gorthner (unpublished data, 1995). Copies of both manuscripts are kept at the Paleontological Research Unit Ghent as part of the collection.

The present paper is essentially a critical review of the fossil material cited above and the published literature on the modern and fossil Lake Malawi malacofauna in the light of our vastly improved knowledge on phylogeny and 
paleontology of the molluscs of the African Great Lakes and of the paleolimnological evolution of these lake basins. The published literature in which provisional species lists of the Chiwondo fossil molluscs or part of them are provided is quite extensive and widely scattered. It includes Pain (1966), Gautier (1966), Gautier (1970), Van Damme (1984, 1988), Van Damme and Pickford (1999, 2003), Gorthner (1994), Gorthner et al. (1992), Schrenk et al. (1995), Schultheiß et al. (2009) and Van Bocxlaer (2010).

\section{The evolution of taxonomic concepts about the modern Malawi malacofauna: from speciose 19th Century Lake Nyasa to species-poor 21st Century Lake Malawi}

The spectacular thalassoid or marine-like fauna of Lake Tanganyika (area: $32900 \mathrm{~km}^{2}$ ) greatly puzzled 19th Century scientists and led to heated debate as to their origin. The comparatively unspectacular molluscs of Lake Nyasa, as L. Malawi formerly was known, saddled them with the subsidiary question why in this equally vast lake (area: $29600 \mathrm{~km}^{2}$ ) no such a diversified thalassoid fauna was found, for according to Bourguignat (1889) only the Nyasan thiarids did possess thalassoid characters. This author, recognizing about 40 thiarid species, divided them in five genera: Melania (= Melanoides) represented only by the ubiquistic $M$. tuberculata and the rest belonging to the endemic genera Nyassia, Nyassella, Micronyassia and Nyassomelania (Fig. 1). He believed that the relatively low species richness was due to insufficient sampling in the at the time virtually unexplored lake.

In the middle of the 20th Century, during what Michel et al. (2003) call "the dawn of Mayrian optimism for the practicality of a single 'biological' species concept", the number of molluscan species in all African lakes was taxonomically decimated. In Lake Malawi none of the endemic thiarid genera survived this taxonomic lumping event and only 16 gastropods are presently considered to live in the lake sensu stricto of which eight are endemic Melanoides (Brown, 1994; Darwall et al., 2005), but the number of the Melanoides endemics is still unresolved (see Table 1). Eldblom and Kristensen (2003) retain three endemics only in the last revision based on morphology. While molecular biologists speak of the "Melanoides polymorpha-complex", considered to be a poly- or paraphyletic group of clones (Genner et al., 2004, 2007b; Von Gersdorff Sørensen et al., 2005). This led Michel et al. (2008) to raise a question about their equivalence to "standard" species, i.e., as defined according to the Biological Species Concept (BSC).

Questions on the morphological distinctiveness and the number of the endemic Bellamya (Viviparidae) and Lanistes (Ampullariidae) have not yet been fully resolved either. Recent molecular investigations of these two other prosobranch "species flocks", considered to have diverged within the lake,

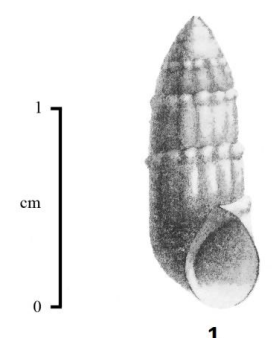

1

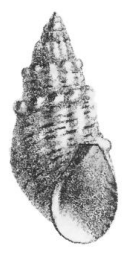

2

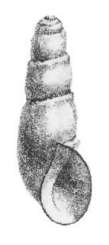

3

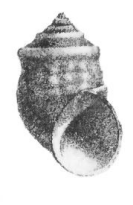

4
Fig. 1. Example of taxonomic hyper-splitting in modern Lake Malawi molluscs. Representatives of the four thiarid genera created by Bourguignat (1889), endemic to Lake Malawi: 1 - Nyassia magnifica; 2 - Nyassella pulchra; 3 - Nyassomelania truncatelliformis and 4 - Micronyassia singularis. All ca. 40 thiarid species recognized by Bourguignat have been shown by molecular research to be parthenogenetic clones belonging to the "Melanoides polymorphacomplex". Some (e.g., Melanoides truncatelliformis) are still "officially" considered as distinct endemic species (Scale bar: $10 \mathrm{~mm}$ ).

revealed that both groups consist not exclusively of in-lake endemics, as was formerly assumed, but of in-lake endemics sensu stricto plus one or two paludal/fluvial species endemic to the whole of the Malawi Basin, i.e., basin endemics (Sengupta et al., 2009; Schultheiß et al., 2009, 2011). Both these Malawi species groups are monophyletic, young and the speciation processes still likely are going on in the viviparid flock (Schultheiß et al., 2011). In addition, the possibility that the clonal Melanoides lineages endemic to lake Malawi are not the result of an in-lake radiation either, but that they are allopatric paleo-endemics that colonized Lake Malawi at different times, is considered a possible scenario in view of their para-/polyphyly (Genner et al., 2007b).

Dudley's (2000) remark that "Malawi gastropod classification is in a continuing state of revision and that it will be some time before a system comes to be generally agreed for the groups of higher rank" is still painfully actual. Certain is that the recent genetic research on Lake Malawi molluscs does not lend support to the ingrained concept of "spectacular" species diversification/radiation in this supposedly longlived "natural laboratory of evolution". The largest Malawi group, that of Melanoides, can only partially result from an in-lake radiation and the two other "clades" are small and genetically little diversified.

Diversification is not spectacular and hence niche partitioning and occupation are neither. Most Malawi species are restricted to the shallow littoral zone with sandy substrate (above $20 \mathrm{~m}$ ) and only a few are found in the deep sublittoral between 40 and $80 \mathrm{~m}$. But at such depths their occurrence is sporadical and the only two species, Lanistes nasutus and Bellamya ecclesi (Fig. 2), possessing morphological adaptations for life at greater depths, are represented by a few rare and highly localized populations (Brown, 1994). The specific shells adaptations in both species consist of the persistence of essentially neotenous traits, namely a thin, rapidly 


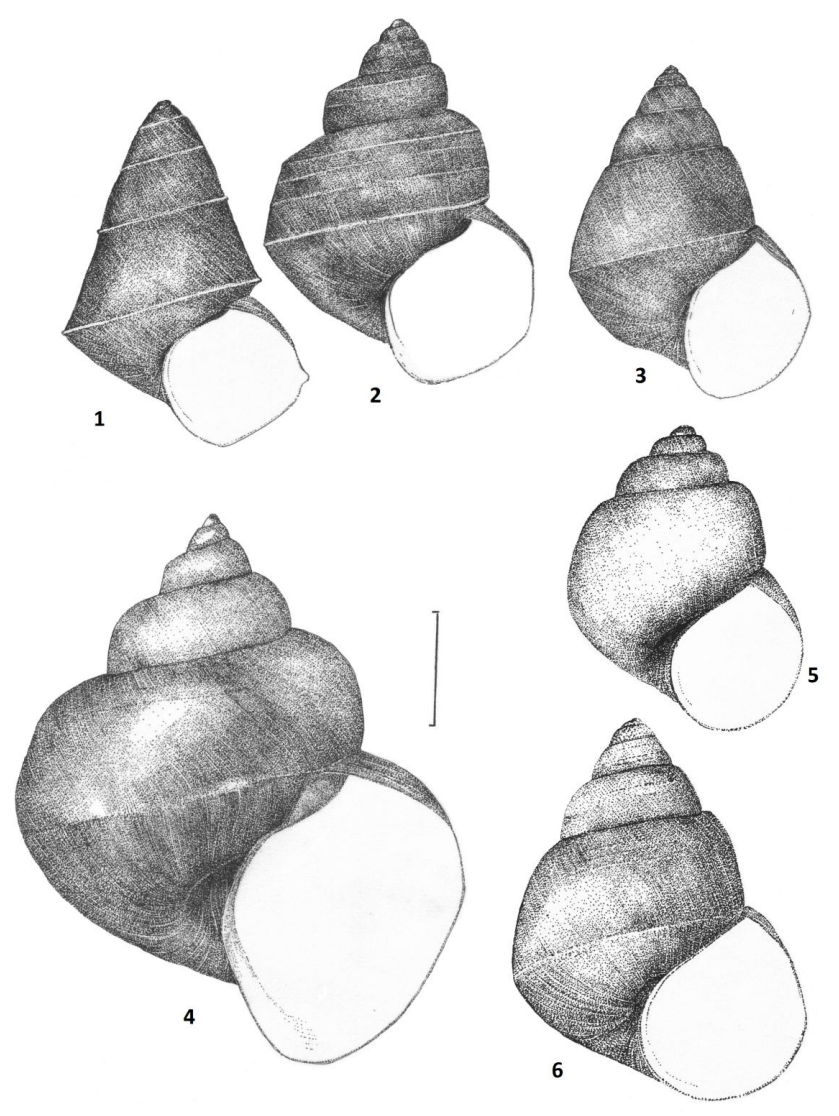

Fig. 2. Example of partly repeated convergent evolution in the Malawi Basin. Two groups of endemic lacustrine Bellamya species (Viviparidae) that evolved in lakes of the Malawi basin separated by ca. 2 million years. The first group, consisting of (1) B. cf. pagodiformis, (2) B. cf. trochlearis, and (3) B. cf. robertsoni, lived in paleo-lake Chiwondo during late Pliocene-early Pleistocene times. The second group, consisting of (4) Bellamya ecclesi, (5) B. jeffreysi and (6) B. robertsoni, occurs in present Lake Malawi. Both groups are not directly affiliated (Scale bar: $10 \mathrm{~mm}$ ).

growing shell, a strongly inflated body whorl and a mouth aperture that is very large compared to the total length and width of the animal, either being strongly elongated as in L. nasutus or wide as in B. ecclesi. Such morphological features increase buoyancy and permit the extension of a large foot, adaptations for life in or on fluid sediment. No special anatomical features are mentioned in literature except for strongly elongated tentacles in L. nasutus (Mandahl-Barth, 1972; Berthold, 1990).

\section{The paleontological data reviewed: the end of Lake Malawi as an ancient lake}

The paleolimnological, pre-Holocene evidence in the Malawi basin is fragmentary and localized. Pliocene-Pleistocene deposits, described as the Chiwondo and the Chitimwe Beds, are exposed at the NW fringe of Lake Malawi near its satellite lake Chiwondo (Fig. 3). For detailed stratigraphic information we refer to Sandrock et al. (2007) and Kullmer (2008). Age estimates are based on suid biochronostratigraphy (= chronostratigraphy based on teeth of fossil pigs (Suidae)). Since no mammal fossils are found at the mollusc bearing sites, their age was based, as well as possible, on stratigraphic correlations with nearby exposures yielding mammals.

According to the authors cited, five limnological stages can be discerned in the Chiwondo region ranging from terminal Miocene to Late Pleistocene times:

- Chiwondo Beds, Unit 1 (time range: > 5 to ca. $4.0 \mathrm{Ma}$ ). Exclusively fluvial deposits, no molluscs.

- Chiwondo beds, Unit 2 (time range: $\geq 4$ to ca. $3.75 \mathrm{Ma}$ ). Lacustrine limestone and silt- to sandstone deposits formed in littoral and margin environments with rare gastropod fossils (Bellamya). At the top of the unit the facies changes to littoral marlstones with abundant gastropods and rare bivalves. The molluscan assemblages are found in consolidated shell beds cropping out as benches with a thickness up to several meters and extending over several hundred meters (Schrenk et al., 1995). Preservation in the coarse sandstone is poor with inner casts and partly dissolved outer casts. In the rare marl- and limestones fossilization is slightly better, consisting of recrystallized calcitic shells.

- Chiwondo Beds, Unit 3 (time range: ca. 3.75 to $2.0 \mathrm{Ma}$ for Subunit 3A and ca. 2.0 to ca. $1.5 \mathrm{Ma}$ for Subunit $3 \mathrm{~b}$ on the basis of suid biochronostratigraphy). The overlying unit, separated from the earlier deposits by an unconformity, is characterized by the return of deltaic/fluvial conditions. Pronounced lake regressions took place between $2.3-2.0 \mathrm{Ma}$ and $1.6-1.5 \mathrm{Ma}$. No molluscan assemblages.

- Chiwondo Beds, Unit 4 (time range: ca. 1.5 Ma to $>20 \mathrm{ka}$ ). Deposits of eolian sands indicate periods of marked aridity but a brief lacustrine transgressive phase is recorded (no molluses).

- Chitimwe Beds (time range: $\leq 20 \mathrm{ka}$ ). Alluvial fan deposits indicate a phase of lacustrine regression. Holocene lacustrine deposits are not present in the NW Lake Malawi region.

The known Chiwondo malacofauna comprises species belonging to the genera Lanistes (2-3 species; Ampullariidae), Bellamya (4 sp.; Viviparidae), Gabbiella (2-3 sp.; Bithyniidae), Cleopatra (1 sp.; Paludomidae), Melanoides (2 sp.; Thiaridae), Bulinus (1 sp.; Planorbidae), Coelatura (2 sp.; Unionidae), Pseudobovaria (1 sp.; Unionidae), Chambardia (1 sp.; Iridinidae), Etheria (1 sp.; Etheriidae) and Corbicula (1 sp.; Cyrenidae) (see Table 1). Many assemblages are 


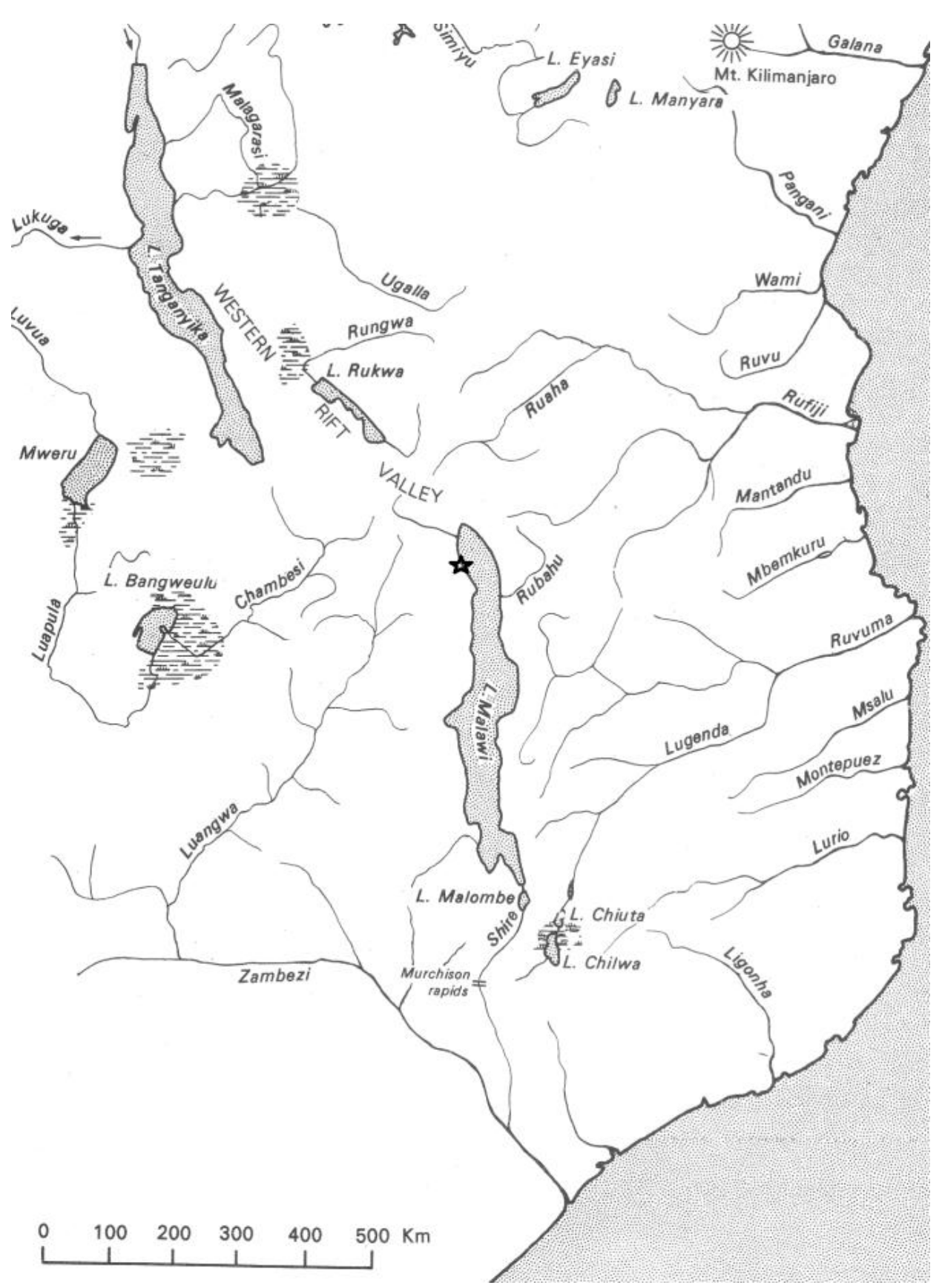

Fig. 3. Modern Lake Malawi and Lake Tanganyika in the African Western Rift (after Beadle, 1974). The location of the fossiliferous Chiwondo Beds is indicated by a star.

species poor with mainly Bellamy, Gabbiella, Melanoides or monospecific with only Bellamya. All appear to have been formed in the littoral storm wave zone and the higher part of the littoral.

Most Chiwondo species, i.e., those belonging to the genera Lanistes, Gabbiella, Melanoides, Bulinus, Coelatura, Pseudobovaria, Chambardia, Etheria and Corbicula are morphologically similar to species that are or were (i.e., Pseu- dobovaria) widespread in East Africa or are endemic to the Malawi Basin (e.g., Chambardia nyassaensis (Graf and Cummings, 2007) and do not show lacustrine adaptations.

A marked diversification can be observed only in the genus Bellamya (Fig. 2.), which apart from an unornamented morph ('Bellamya capillata" auctores) is represented by (1) a form with sloping, flattened whorls and a basal carina, described by A. Gautier (unpublished data, 1968) and cited 
in Van Damme and Pickford (1999) as Bellamya cf. pagodiformis for the likeness with the modern Lake Mweru species, (2) a carinated form, $B$. cf. trochlearis, resembling the modern Lake Victoria endemic and (3) B. cf. robertsoni, which is morphologically quite similar to the present-day Lake Malawi $B$. robertsoni but smaller. The unornamented $B$ capillata is dominant, all others are relatively rare. The morphological differences suggest a para- or polyphyletic origin of the Chiwondo Bellamya-group. That these Chiwondo lacustrine endemics are ancestral to the present ones is highly unlikely, considering the evidence for intermittent aridity and salinity peaks during the Pleistocene (see paleoenvironmental reconstruction of Pleistocene events). As to a continuity in Melanoides, the morphological divergence and dwarfism observed in the modern Malawi representatives is not found in the Chiwondo assemblages, where the taxon is represented by two large sized forms with no distinct correlations to the modern clade (see also further).

Generally the Chiwondo littoral malacofauna is surprisingly similar in diversity and composition to the earlymiddle Holocene fauna (Van Boxclaer, 2004), at least in comparison to the marked differences between Pliocene and Holocene-modern faunas in paleo-lakes of the Turkana and the Albertine basins. It is safe to conclude that during late Pliocene times the Chiwondo lake fauna did already consist for an important part of the same ubiquistic and basin endemic taxa occurring in the present lake and that the composition of the late Pliocene faunal community was in many aspects already "modern". The only "ancient" taxon present, be it rare, in the Chiwondo assemblages is the unionid Pseudobovaria. In the two other basins mentioned, Pliocene fauna elements remain dominant until the period ca. $1.8 \mathrm{Ma}$ to ca. 1.2 Ma (see further).

That the Chiwondo malacofauna dates from the early Pliocene, that is from $4-3.8 \mathrm{Ma}$ as proposed by Sandrock et al. (2007) and Kullmer (2008), is difficult to accept, not primarily because that would infer that the Malawi fauna had reached its modern aspect millions of years earlier than those of other East African basins, but because of the presence of the Asiatic bivalve Corbicula. The presence of fossils of this Asian clam provides a terminus ante quem date of 2.6-2.5 Ma for African assemblages. Well-calibrated evidence comes from the Turkana Basin where Corbicula appears for the first time in deposits of the short-lived paleolake Lokeridede directly overlying the Burgi Tuff, dated to $2.68 \pm 0.06 \mathrm{Ma}$ (Feibel et al., 1989; McDougall and Brown, 2008). Fossil Corbicula from the Kada Me'e Tuff Complex in the Hadar Formation are dated at ca. 3.4 Ma, but this in an estimate obtained by interpolation of six ${ }^{40} \mathrm{Ar} /{ }^{39} \mathrm{Ar}$ analytical data and considered as unreliable (Campisano, 2007; Campisano and Feibel, 2008).

The terminus ante quem date based on the molluscs is 1.5 to $1.2 \mathrm{Ma}$, i.e., the last records of the extinct unionid Pseudobovaria (Van Damme and Pickford, 2010). The age of all molluscan Chiwondo assemblages should, consider- ing the absence of any marked morphologically differences among the assemblages, be considered as being broadly similar, hence deposited either around 2.5 Ma or around 1.9 Ma. In East Africa the 2.7-2.4 Ma interval appears to be a major lake period suggested by the moisture history of the Ethiopian, Kenyan and Tanzanian rift basins (Trauth et al., 2005, 2007, 2010; Tiercelin et al., 2010). Important incursions of invasive species (e.g., Corbicula) synchronously in the Turkana Basin (Van Bocxlaer et al., 2008) and the Albertine Basin (Van Damme and Pickford, 2003, 2010) indicate a significant increase of hydrological connections among different basins during the time segment. Paleo-lake Chiwondo may hence have existed synchronously with paleolake Lokeridede (ca. 2.5 Ma) of the Turkana basin and with the earlier stages of paleo-lake Kaiso and paleo-lake Lusso (ca. $2.5 \mathrm{Ma}$ ) of the Albertine basin. An alternative possibility is that it existed during the same period as paleo-lake Lorenyang (ca. 2.0-1.8 Ma) in the Turkana Basin and the terminal stages of both aforementioned lakes in the Albertine Basin (ca. 2.0-1.8 Ma) (Van Damme and Van Bocxlaer, 2009; Van Damme and Pickford, 2010), present during an equally wide spread East African wet phase (Trauth et al., idem). In the latter period the Pliocene fauna elements in the two basins were disappearing also.

As in other parts of East Africa, periods of increasingly aridification and climatic instability are recorded in the Malawi Basin throughout the whole Pleistocene period with extremely low lake levels between $2.3-2.0 \mathrm{Ma}$ in late Pliocene times and between 1.6-1.5 Ma during Lower Pleistocene times, in Unit $3 \mathrm{~b}$ of the Chiwondo Beds. In the overlying Unit 4, eolian sands equally indicate phases of hyperaridity during the rest of the early and middle Pleistocene (Sandrock et al., 2007). The intermittent occurrence of discrete but extreme periods of aridity during the Late Pleistocene and the dramatic degradation of the freshwater lacustrine ecosystem has been reconstructed in detail via the multidisciplinary study of Malawi lake cores (Cohen et al., 2007). Hyper-aridity is noted in the period between 135 to $90 \mathrm{ka}$, when the strongly constricted lake was shallow, holomictic and saline, surrounded by semi-desert.

From Pleistocene times only a single, brief high lake level stand of unknown age, younger than $1.5 \mathrm{Ma}$, and without fossils is recorded (Sandrock et al., 2007). This event may possibly fall within the late in the early Pleistocene period of major global climatic transition, situated at 1.1 to $0.9 \mathrm{Ma}$ by Trauth et al. (2007), or it results from local climatic events. The absence of macrofossils may be due to unfavourable conditions for fossilisation, but more likely indicates the absence of macroscopic life (hypersalinity/hyper-alkalinity). For the whole of the Pleistocene, information about molluscan life in the Malawi Basin is hence missing. The lacustrine ecosystem during that epoch must have fluctuated between a Lake Baringo-Lake Naivasha type of lake, i.e., with a conductivity in excess of 4000$4500 \mu \mathrm{S} \mathrm{cm}^{-1}$ without freshwater prosobranchs or bivalves 
and a Lake Turkana-Lake Langano type with a conductivity around 2200-2300 $\mu \mathrm{S} \mathrm{cm}^{-1}$, with only Melanoides and Gabbiella still present but dwarfed (Van Damme, 1976; Brown, 1994).

The chances that populations of oligohaline taxa, such as the gastropod Bellamya (Viviparidae) and Cleopatra (Paludomidae) and equally sensitive bivalves such as Coelatura and Nyassunio (Unionidae), Mutela and Pleiodon (Iridinidae) and Etheria (Etheriidae), could survive these intermittent aridity/hyper-aridity peaks in the restricted and endorheic Malawi Basin, i.e., prior to the connection with the Zambezi Basin via the River Shire, were nil. These groups must have re-invaded the Malawi Basin, when environmental conditions improved in the Late Pleistocene. The morphological likeness between modern Bellamya robertsoni and terminal Pliocene-early Pleistocene $B$. cf. robertsoni (Fig. 2) does therefore not imply direct parentage, in particular since the modern robertsoni morph is not yet clearly discernible in the late Holocene Malawi deposits (Van Bocxlaer, 2004; Van Bocxlaer and Van Damme, 2009).

Taxa such as Melanoides (Thiaridae) and Gabbiella (Bithyniidae) tolerate relatively high salinity concentrations and taxa such as Lanistes (Ampullariidae) and Chambardia (Iridinidae) are able to aestivate during extended dry periods (Van Damme, 1984). Populations of these taxa may have survived the Pleistocene salinity crises and modern representatives in the basin or in the lake such as Lanistes ellipticus, Gabbiella stanleyi and Chambardia nyassaensis may derive from basin endemics already present during Chiwondo times. However, the molecular evidence concerning the Malawi Lanistes, indicates that the formation of this group is young (Middle Pleistocene?) (Schultheiß et al., 2009).

For the modern representatives of the genus Melanoides, the case is more complex. They are not yet present in Chiwondo times and may be dwarfed morphs that originated during Pleistocene times in the saline lakes, but that these morphs are descended from populations already present in the basin during Chiwondo times (Genner et al., 2007b) cannot be ascertained. The dominant fossil Chiwondo Melanoides was identified as $M$. cf. nodicincta, a modern Lake Malawi endemic, by A. Gautier (unpublished data, 1968), cited in Van Damme (1984) and Van Damme and Pickford (2003), but this identification is incorrect. The Chiwondo shells are too poorly preserved to provide a specific attribution. Presently it seems best to consider them to belong to the $M$. polymorpha-M. mweruensis $-M$. anomala species group, occurring in the south-eastern African region (Van Bocxlaer, 2010). Using these Chiwondo fossils to calibrate the molecular clock in calculating the age of the modern M. polymorpha-group should be avoided (Genner et al., 2007b).

\section{Is the Pleistocene climatic destabilization responsible for major extinctions and major evolutionary radiations in the molluscs of the African rift lakes?}

The reconstruction of the malacological history of the Malawi basin, though fragmentary, shows that as in the two other East African basins with a fossil record, Lake Turkana and Lake Albert basin, a diversified lacustrine fauna existed in the basin during late Pliocene times. It contained lacustrine endemics and definitely possessed already a distinct southeastern African character, clearly different from that of the other basins mentioned. The age of this paleo-lake Chiwondo fauna is uncertain. It certainly is not older than $2.7-2.6 \mathrm{Ma}$ but it could be younger, i.e., dating from the East African wet phase at 2.0-1.9 Ma.

After that period, possibly from ca. $1.8 \mathrm{Ma}$ and definitely after 1.5 Ma, the old Pliocene malacofauna in the Turkana and Albertine basins shows signs of a severe deterioration. In the Albertine Basin the Miocene-Pliocene Congolian faunal elements are replaced by an impoverished eurytopic fauna of the "Nilotic" type around 1.8 Ma (Van Damme and Pickford, 1999, 2003, 2010). In the Turkana basin virtually all old Pliocene basin elements are definitely gone after ca. 1.3 to 1.2 Ma, i.e., after the brief lake interval around ca. 1.4 Ma at the base of Member L, Shungura Formation (Van Bocxlaer et al., 2008).

The paleo-environmental data for the Malawi Basin we possess indicate the instauration of hyper-arid phases possibly already from about $2.3 \mathrm{Ma}$, if the mammalian chronostratigraphy of Sandrock et al. (2007) is followed. It can be assumed that in the Malawi Basin all molluscan lake endemics must have become extinct prior to $1.8 \mathrm{Ma}$ and that most of the basin endemics, possibly except those with adaptations to survive extended periods of aridity, e.g., Chambardia nyassaensis, or significant increases in salinity, e.g., Gabbiella stanleyi, also were gone after ca. 1.3 to $1.2 \mathrm{Ma}$.

In all larger East African basins, where according to the fossil evidence an endemic lake fauna developed during late Miocene-Pliocene times, all Pliocene lacustrine endemics and many basin endemics appear to have become extinct during the hyper-arid early Pleistocene times. In all smaller basins such as those in the Gregory and Ethiopian rift, fossil mollusc assemblages from Pliocene freshwater lakes are also known, but intense level fluctuations, endorheism and volcanic activity only permitted short lived incursions of eurytopic species and no evolution (Van Damme, 1984).

In their study on the evolution of the modern endemic Lanistes clade of Lake Malawi, Schultheiß et al. (2009) extend the debate concerning possible evolutionary patterns in molluscs to all large African lakes. They discern three types of lacustrine ecosystems based on the criterion that tempo and mode of molluscan evolution are primarily determined by the degree of ecosystem stability on a geological timescale. At one end they place "seemingly" stable systems but which are, viewed on a geological timescale, instable and 
Table 1. Freshwater molluscs from terminal Pliocene-early Pleistocene Paleo-Lake Chiwondo and modern Lake Malawi. Taxonomy and range of modern species according to Brown (1994) and Graf and Cummings (2007) except when mentioned otherwise.

\begin{tabular}{|c|c|c|c|}
\hline Taxon & $\begin{array}{c}\text { Paleo- } \\
\text { Lake } \\
\text { Chiwondo }\end{array}$ & $\begin{array}{l}\text { Modern } \\
\text { Lake } \\
\text { Malawi }\end{array}$ & Remarks \\
\hline
\end{tabular}

GASTROPODA

\begin{tabular}{|c|c|c|c|}
\hline \multicolumn{4}{|l|}{ Viviparidae } \\
\hline $\begin{array}{l}\text { Bellamya capillata } \\
\text { fide Brown }\end{array}$ & $\mathrm{x}$ & $\mathrm{x}$ & $\begin{array}{l}\text { Wide spread SE-African species, but modern Malawi Basin populations differ } \\
\text { genetically and the name Bellamya simonsi Bgt, a basin endemic, has preference }\end{array}$ \\
\hline Bellamya jeffreysi & - & $\mathrm{x}$ & Modern lake endemic, absent in early Holocene L. Malawi deposits \\
\hline Bellamya robertsoni & & $\mathrm{x}$ & Modern lake endemic, absent in early Holocene L. Malawi deposits \\
\hline Bellamya cf. robertsoni & $\mathrm{x}$ & - & $\begin{array}{l}\text { Lake endemic. Morphological convergence with modern species from } \\
\text { L. Malawi }\end{array}$ \\
\hline Bellamya ecclesi & - & $\mathrm{x}$ & Modern lake endemic known only from deeper water in southern L. Malawi \\
\hline Bellamya cf pagodiformis & $\mathrm{x}$ & - & $\begin{array}{l}\text { Lake endemic. Morphological convergence with modern species from } \\
\text { L. Mweru }\end{array}$ \\
\hline Bellamya cf. trochlearis & $\mathrm{x}$ & - & $\begin{array}{l}\text { Lake endemic. Morphological convergence with modern species from } \\
\text { L. Victoria }\end{array}$ \\
\hline
\end{tabular}

\section{Ampullariidae}

Lanistes ovum fide Brown

Lanistes ellipticus

Lanistes solidus

Lanistes cf. solidus

Lanistes nyassanus

Lanistes nasutus

\section{Bithyniidae}

Gabbiella stanley

Gabbiella cf. stanley

Gabbiella sp.

?Valvatidae

?Valvata sp.

\section{Paludomidae}

Cleopatra sp.

\section{Thiaridae \\ Melanoides tuberculata \\ Melanoides nodicincta \\ Melanoides pergracilis \\ Melanoides cf. pergracilis \\ Melanoides pupiformis \\ Melanoides turritispira \\ Melanoides polymorpha \\ Melanoides cf. polymorpha \\ Melanoides nyassana \\ Melanoides truncatelliformis \\ Melanoides magnifica \\ Melanoides simonsi \\ Melanoides virgulata}

Lymnaeidae

Lymnaea natalensis

$\begin{array}{cc}\mathrm{X} & \mathrm{x} \\ \mathrm{X} & \mathrm{x} \\ - & \mathrm{x} \\ ? & - \\ - & \mathrm{x} \\ - & \mathrm{x}\end{array}$

Widespread in Africa but modern Malawi Basin populations differ genetically and the name Lanistes ingens Ancey, a basin endemic, hence has preference.

Basin endemic, not found in the lake proper

Lake Malawi endemic (?) nearly indistinct from L. ellipticus

Only a few badly preserved specimens possibly belong to this species

Modern Lake Malawi endemic, not found in early Holocene deposits

Modern Lake Malawi deep water species, only known from a dozen specimens

$-\quad x$

$\mathrm{x}$

$\mathrm{x}$

Costulate ovate species, identified by Van Damme (1976) as Valvata, but more likely belonging to the Assiminaeidae

Basin endemic with modest carinae, probably belonging to the $\mathrm{Cl}$. smithi/ Cl. mweruensis group from Zambia. Genus presently absent in the Malawi basin.

Mainly in vegetation in Lake Malawi shallows, probably basin endemic Morphological identical to modern species, probably basin endemic Exceptionally large Gabbiella species, related to the above. Lake endemic?

Widespread Oriental species

Clone, endemic to modern L. Malawi

Clone, endemic to modern L. Malawi

Very slender form, ca. twice the size of modern M. pergracilis

Clonal dwarfed form, endemic to L. Malawi

Clonal dwarfed form, endemic to L. Malawi

Modern Lake Malawi endemic. Extremely polymorphic species

Erroneously mentioned as $M$. cf. nodicincta by Van Damme and Pickford (2003)

Clonal dwarfed form, endemic to L. Malawi

Clonal dwarfed form, endemic to L. Malawi

Clonal dwarfed form, endemic to L. Malawi

Considered distinctive from M. nodicincta by Eldblom and Kristensen (2003)

Invasive Oriental species in modern L. Malawi (Eldblom and Kristensen, 2003) 
Table 1. Continued.

\begin{tabular}{|c|c|c|c|}
\hline Taxon & $\begin{array}{l}\text { Paleo- } \\
\text { Lake } \\
\text { Chiwondo }\end{array}$ & $\begin{array}{l}\text { Modern } \\
\text { Lake } \\
\text { Malawi }\end{array}$ & Remarks \\
\hline Biomphalaria pfeifferi & - & $\mathrm{x}$ & Ubiquistic. S. America genus that invaded Africa probably in Pleistocene times \\
\hline Ceratophallus natalensis & - & $\mathrm{x}$ & Widespread \\
\hline Gyraulus costulatus & - & $\mathrm{x}$ & Widespread \\
\hline Bulinus nyassanus & - & $\mathrm{x}$ & Modern Lake Malawi endemic, also present in early Holocene deposits \\
\hline Bulinus succinoides & - & $\mathrm{x}$ & Modern Lake Malawi endemic \\
\hline Bulinus forskalii & - & $\mathrm{x}$ & Widespread \\
\hline \multicolumn{4}{|l|}{ BIVALVIA } \\
\hline Coelatura mossambicensis & - & $\mathrm{x}$ & Widespread south-eastern African species \\
\hline Coelatura cf. mossambicensis & $\mathrm{x}$ & - & Probably identical to the modern species \\
\hline Coelatura sp. & $\mathrm{x}$ & - & $\begin{array}{l}\text { Very large Coelatura, resembling modern } C \text {. briarti, widespread in the Congo } \\
\text { Basin }\end{array}$ \\
\hline $\begin{array}{l}\text { Pseudobovaria mwayana } \\
\text { tuberculata }\end{array}$ & $\mathrm{x}$ & - & $\begin{array}{l}\text { Extinct genus en species represented by the subsp. tuberculata, equally } \\
\text { found in the L. Turkana and Albert Basin, where it is restricted to early } \\
\text { Pleistocene strata. }\end{array}$ \\
\hline \multicolumn{4}{|l|}{ Iridinidae } \\
\hline Aspatharia subreniformis & - & $\mathrm{x}$ & Widespread \\
\hline Chambardia nyassaensis & $\mathrm{x}$ & $\mathrm{x}$ & Ranging from L. Rukwa (Tanganyikan basin) to L. Malombe (Malawi Basin) \\
\hline \multicolumn{4}{|l|}{ Etheriidae } \\
\hline \multicolumn{4}{|l|}{ Sphaeriidae } \\
\hline Pisidium pirothi & - & $\mathrm{x}$ & Widespread \\
\hline Pisidium reticulatum & - & $\mathrm{x}$ & Widespread \\
\hline
\end{tabular}

intermittently cease to exist as large standing freshwater bodies. As an example, they cite Lake Victoria that dried out in Late Pleistocene times. In such type of lake radiation events may be triggered during renewed freshwater phases but there is no continuity in the molluscan lineages involved. On the other end they place the Lake Tanganyika ecosystem characterized by long-term stability of the abiotic setting. The authors claim that the endemic radiations within lakes like Lake Tanganyika or Lake Baikal "have regularly proved to be remarkably old". The lacustrine ecosystem in the Malawi Basin is considered by them as an intermediate.

We fail to see why the lacustrine malacofaunas in the Lake Malawi basin should be given this special status. The data advanced in this paper indicate that regardless of these depth and size, all African freshwater systems, that in the Lake Malawi Basin included, crashed during the Pleistocene and that their endemic intra-lacustrine faunas went extinct. The only exception is Lake Tanganyika (Fig. 3). However, while part of the Pliocene malacofauna survived in that lake, there are no indications that the intra-lacustrine molluscan radiations in it are remarkably old. Most Tanganyikan mollusc taxa are paleo-endemics, not neo-endemics, as shown by paleontological (Van Damme and Pickford, 2003, 2010), molecular (Wilson et al., 2004) and morphological (Glaubrecht, 2008) evidence. Though significant lake level drops did occur during the late Pliocene and Pleistocene 
(ca. $435 \mathrm{~m}$ level drop during the early Late Pleistocene megadrought, McGlue et al., 2008), the Tanganyikan freshwater system did not crash, and the lake acted as a refuge for a number of taxa, e.g., the viviparid genus Neothauma, that became extinct in the Albertine basin around $1.8 \mathrm{Ma}$ (Van Damme and Pickford, 1999). Consequently, the molluscan in-lake diversification processes observed in some of the Tanganyikan paludomid tribes such as Lavigeria may be quite young.

Convincing arguments that abiotic changes did have a severe impact on Lake Tanganyika's fauna have recently been found by molecular phylogenetic research, e.g., on molluscivorous plathytelphusid crabs, limnochromine cichlids, Synodontis catfish and mastacembelid eels. The studies indicate that the radiations in these groups are geologically recent events (late Pliocene-early Pleistocene; Cumberlidge et al., 1999; Marijnissen et al., 2006, 2008; Duftner et al., 2005; Day and Wilkinson, 2006; Brown et al., 2010). Since speaking in geological terms, the specialized molluscivorous crabs evolved only recently, the onset of the radiation in the thalassoid Lavigeria and others, considered to result from an armsrace between crabs and their prey (West et al., 1992), must also date from late Pliocene or early Pleistocene times at the earliest. The quite impressive Holocene radiation of Lavigeria in Lake Rukwa (Fig. 3), when this lake was joined with Lake Tanganyika via the Karema Gap (Cox, 1939; Cohen et al., 2010) may indicate that the evolutionary divergence process in Lavigeria is still an ongoing process. On-going divergence is also suggested for the plathytelphusid crabs (Marijnissen et al., 2008).

In all East African lakes the current molluscan radiations are recent events, postdating the Pliocene-Pleistocene aridity crises. Lake Tanganyika excepted, the populations involved in the modest modern radiation events belong to Pleistocene invaders replacing older Pliocene in-lake lineages that went extinct. In Lake Tanganyika the increased environmental stress triggered a spectacular radiation but only in a single taxon, Lavigeria, the latest estimate of this clade being ca. 43 species (Ngereza, 2010). This marked radiation in Lake Tanganyika may also indicate that considerable ecospace became available due to the extinction of other groups. The Lavigeria radiation certainly is the result of an in-lake process, and the onset of this divergence-event probably falls in the same time segment as the extinction-events in the other lakes. That the genus is an ancient occupant of the lake is not even certain since a closely related taxon (Potadomoides) occurs in the Malagarasi and Luapula (Brown, 1994) and an invasion or multiple invasions could have occurred during transgressive periods throughout Pliocene-Pleistocene times.

\section{Conclusions}

The available data indicate that probably already during late Pliocene times a marked basin endemism had developed in the Malawi malacofauna, in Lanistes, Gabbiella and Chambardia. In the paleo-lake that formed subsequently in this basin during an East African late Pliocene wet phase, intralacustrine divergence processes were initiated but ended abruptly due to increasing aridity crises. The modern lake fauna has no direct relation with the late Pliocene one, possibly except for some salinity or drought resistant species, such as respectively Gabbiella stanleyi and Chambardia nyassaensis. The fact that in modern Lake Malawi the colonization of the lacustrine environment remains mainly restricted to sandy bottoms of the upper epilimnion suggests that even now, during the present freshwater optimum, exploitation of the available space and niches is suboptimal. The cycle of extinction and incipient radiation in the Malawi molluscs seems to have been the norm in the African rift lakes since late Pliocene times regardless of their size and depth. The only exception appears to be Lake Tanganyika, that seems to have acted primarily as a refugium for part of the older Pliocene malacofauna during Pleistocene megadroughts and not as a center of in-lake evolution. Apparently in Lake Tanganyika the Pleistocene climatological destabilization was insufficient to cause the freshwater ecosystem to crash, but it nevertheless altered the limnological environment so drastically that spectacular divergence processes started, e.g., in plathythelphusid crabs and in one thallasoid molluscan taxon, Lavigeria.

The terminal Pliocene-early Pleistocene aridity crises had continent-wide impact on the African malacofauna and this geological abrupt event did initiate major extinctions as well as radiations. Therefore, we propose that the beginning of the Pleistocene is used as a reference point in calibrating molecular clocks for African freshwater mollusc phylogeny instead of estimates of the age suggested for the earliest formation of a lake in any given rift basin. This proposal is consistent with recent molecular clock divergency estimates for several Tanganyikan non-molluscan groups (see higher), though some of these estimates place this event around the very onset of the Pleistocene or Gelasian Stage, i.e., between ca. 3-2 Ma. Here a slightly younger age of ca. 1.8-1.6 Ma, i.e., late in the early Pleistocene at the beginning of the Calabrian Stage, is proposed, since this coincides with a time of major molluscan extinctions and extreme aridity in East Africa (Trauth et al., 2005, 2007, 2010). A late in the early Pleistocene or even a Middle to Late Pleistocene date is also consistent with molecular clock divergence time estimates of modern Lake Malawi molluscs (Genner et al., 2007b; Schultheiß et al, 2009, 2011), modern Lake Malawi Bathyclarias, Clariidae (Agnèse and Teugels, 2001), Mbuna and non-Mbuna cichlids (Won et al., 2005, 2006) and of cichlids in paleolake Makgadikgadi and in modern L. Victoria (Genner et al, 2007a) . 
Acknowledgements. The first author likes to thank Christian Albrecht, Department of Animal Ecology \& Systematics, Justus Liebig University, for inviting him to write this article and for his patience and support. The two anonymous referees and the editor, Roland Schultheiß, are thanked for their constructive comments. Both authors wish to thanks Jacques Verniers, Research Unit Paleontoloy, Ghent University for financial and logistic support.

Edited by: R. Schultheiß

\section{References}

Agnèse, J. F. and Teugels, G. G.: The Bathyclarias-Clarias species flock. A new model to understand rapid speciation in African great lakes, C. R. Acad. Sci. III, 324, 683-688, 2001.

Beadle, L. C.: The Inland Waters of Tropical Africa, An Introduction to Tropical Limnology, Longman Inc., New York, 1974.

Berthold, T.: Phylogenetic relationships, adaptations and biogeographic origin of the Ampullariidae (Mollusca, Gastropoda) endemic to Lake Malawi, Africa, Abh. Nat. Ver., 31/32, 85-118, 1990.

Bourguignat, J. R.: Mélanidées du lac Nyassa suivies d'un aperçu comparatif sur la faune malacologique de ce lac avec celle du grand lac Tanganika, B. Soc. Malacol. Fr., 6, 1-66, 1889.

Brown, D. S.: Freshwater snails of Africa and their medical importance, 2nd Edn., Taylor and Francis, London, 1994.

Brown, K., Rüber, L., Bills, R., and Day, J.: Mastacembelid eels support Lake Tanganyika as an evolutionary hotspot of diversification, BMC Evol. Biol., 10, 188, doi:10.1186/1471-2148-10$188,2010$.

Campisano, C.: Tephrostratigraphy and hominin paleoenvironments of the Hadar Formation, Afar Depression, Ph.D. dissertation, State University of New Jersey, 601 pp., 2007.

Campisano, C. J. and Feibel, C. S.: Tephrostratigraphy of the Hadar and Busidima Formations at Hadar, Afar Depression, Ethiopia, Geol. S. Am. S., 446, 135-162, 2008.

Clark, J. D., Stephens, S., and Coryndon, S.: Pleistocene Fossiliferous Lake Beds of the Malawi (Nyasa) Rift: A Preliminary Report, American Anthropologist, New Series 68(2), Part 2: Recent Studies in Paleoanthropology, 46-87, 1966.

Cohen, A., Stone, J., Beuning, K., Park, L., Reinthal, P., Dettman, D., Scholz, C., Thomas, C., Johnson, T., King, J., Talbot, M., Brown, E., and Ivory, S.: Ecological consequences of early Late Pleistocene megadroughts in tropical Africa, P. Natl. Acad. Sci., 104, 16422-16427, 2007.

Cohen, A. S., Todd, J., McGlue, M., Michel, E., Nkotagu, H., and Grove, A. T.: Paleobiogeographic connections between the African Rift Lakes: an example from the Lake Rukwa Basin and implications for the intralacustrine dispersal of species flocks, in: African Lakes and Paleolakes: Processes, Paleoenvironments, and Paleoclimate, GSA Denver Annual Meeting (31 October-3 November 2010), Abstracts with Programs, 42, 405, 2010.

Cox, L. R.: Mollusca from the Quaternary deposits of Lake Rukwa (Tanganyika Territory), Proc. Malacol. Soc. London, 23, 242252, 1939.

Crowley, T., Pain, T., and Woodward, F.: A monographic review of the mollusca of Lake Nyasa, Ann. Mus. Roy. Afrique Centrale, Série in-8o, Sciences Zoologiques, 131, 1-55, 1964.
Cumberlidge, N., Sternberg, R. V., Bills, I. R., and Martin, H. A.: A revision of the genus Platythelphusa A. Milne-Edwards, 1887 from Lake Tanganyika, East Africa (Decapoda: Potamoidea: Platythelphusidae), J. Nat. History, 33, 1487-1512, 1999.

Darwall, W., Smith, K., Lowe, T., and Vié, J.-C.: The status and distribution of freshwater biodiversity in Eastern Africa, IUCN SCC Freshwater Biodiversity Assessment Programme, IUCN Publication Unit, Cambridge, 36 pp., 2005.

Day, J. and Wilkinson, M.: On the origin of the Synodontis catfish species flock from Lake Tanganyika, Biol. Lett., 2, 548-552, 2006.

Dudley, C.: Freshwater molluscs of the Zambezi River Basin, in: Biodiversity of the Zambezi Basin wetlands, edited by: Timberlake, J. R., Harare, Zimbabwe: Biodiversity Foundation for Africa, Bulawayo/The Zambezi Society, 487-526, 2000.

Duftner, N., Koblmüller, S., and Sturmbauer, C.: Evolutionary relationships of the limnochromini, a tribe of benthic deepwater cichlid fish endemic to Lake Tanganyika, East Africa, J. Mol. Evol., 60, 548-552, 2005.

Eldblom, C. and Kristensen, T.: A revision of the genus Melanoides (Gastropoda: Thiaridae) in Lake Malawi, Afr. Zool., 38, 357369. 2003.

Feibel, C. S., Brown, F. H., and McDougall, I.: Stratigraphic context of fossil hominids from the Omo Group deposits, northern Turkana Basin, Kenya and Ethiopia, Am. J. Physiol. Anthropol., 78, 595-622, 1989.

Gautier, A.: Mollusca, in: Pleistocene Fossiliferous Lake Beds of the Malawi (Nyasa) Rift: A Preliminary Report, edited by: Clark, J. D., Stephens, S., and Coryndon, S., American Anthropologist, New Series 68(2), Part 2: Recent Studies in Paleoanthropology, 46-87, 1966.

Gautier, A.: Late Cenozoic freshwater molluscs of the Chiwondo Beds (Lake Malawi Basin), Text + photographs containing a full taxonomic account of the material collected by Clark et al. and prepared for the planned volume on the Chiwondo Beds that remained unpublished, 38 pp., 1968.

Gautier, A.: The freshwater molluscs from the Chiwondo Beds (Malawi), A preliminary report, Quaternaria, 13, 325-330, 1970.

Genner, M., Michel, E., Erpenbeck, D., De Voogd, N., Witte F., and Pointier, J.: Camouflaged invasion of Lake Malawi by an Oriental gastropod. Mol. Ecol., 13, 2135-2141, 2004.

Genner, M., Seehausen, O., Lunt, D., Joyce, D., Shaw, P., Carvalho, G., and Turner, G.: Age of Cichlids: New Dates for Ancient Lake Fish Radiations, Mol. Biol. Evol., 24, 1269-1282, 2007a.

Genner, M., Todd, J., Michel, E., Erpenbeck, D., Jimoh, A., Joyce, D., Piechocki, A., and Pointier, J.-P.: Amassing diversity in an ancient lake: evolution of a morphologically diverse parthenogenetic gastropod assemblage in Lake Malawi, Mol. Ecol., 16, 517-530, 2007b.

Glaubrecht, M.: Adaptive radiation of thalassoid gastropods in Lake Tanganyika, East Africa: morphology and systematization of a paludomid species flock in an ancient lake, Zoosyst. Evol., 84, 71-12, 2008.

Gorthner, A.: Grenzen paläontologischer Systematik und Stratigraphie in lakustrischen Biotopen am Beispiel rezenter und fossiler Mollusken des Malawisees, Neues Jahrb. Geol. P.-M., 1994, 487-500, 1994.

Gorthner, A.: Stratigraphical and ecological implications from molluscs of the Chiwondo Beds (Plio-Pleistocene/Malawi), Neues 
Jahrb. Geol. P., unpublished, 1995.

Gorthner, A., Schrenk, F., Bromage, T. G., and Ring, U.: Evolution and palaeoecology of the Malawi Rift (Central Africa), Occ. P. Malawi Dep. Antiquit., 1, 23-43, 1992.

Graf, D. L. and Cummings, K. S.: Zambongo! Freshwater Mussels of the Congo and Zambezi Rivers of Africa, Mussel Project, Philadelphia, 104 pp., 2007.

Kullmer, O.: The Fossil Suidae from the Plio-Pleistocene Chiwondo Beds of Northern Malawi, Africa, J. Vertebr. Paleontol., 28, 208216, 2008.

Marijnissen, S., Michel, E., Daniels, S., Erpenbeck, D., Menken, S., and Schram, F.: Molecular evidence for recent divergence of Lake Tanganyika endemic crabs (Decapoda: Platythelphusidae), Mol. Phylogenet. Evol., 40, 628-634, 2006.

Marijnissen, S., Michel, E., Todd, J., Kamermans, M., Olaya-Bosch, K., Kars, M., Cleary, D., van Loon, E., Rachello Dolmen, P., and Menken, S.: Ecological correlates of species differences in the Lake Tanganyika crab radiation, Hydrobiologia, 615, 81-94, 2008.

McDougall, I. and Brown, F.: Geochronology of the pre-KBS Tuff sequence, Omo Group, Turkana Basin, J. Geol. Soc., 165, 549562, 2008.

McGlue, M., Lezzar, K. E., Cohen, A. S., Russell, J. M., Tiercelin, J.-J., Felton, A., Mbede, E., and Nkotagu, H.: Seismic records of late Pleistocene aridity in Lake Tanganyika, tropical East Africa, J. Paleolimnol., 40, 635-653, 2008.

Michel, A. E., Cohen, A. S., West, K., Johnston, M., and Kat, P.: Large African Lakes as Natural Laboratories for Evolution: Examples from the endemic gastropod fauna of Lake Tanganyika, Mitt. Internat. Verein. Limnol., 23, 85-99, 1991.

Michel, E.: Phylogeny of a gastropod species flock: exploring speciation in Lake Tanganyika in a molecular framework, in: Ancient Lakes: Biodiversity, Ecology and Evolution, edited by: Rossiter, A. and Kawanabe, H., Adv. Ecol. Res., 31, 275-300, 2000.

Michel, E., Todd, J., Cleary, D., Kingma, I., Cohen, A., and Genner, M.: Scales of endemism: challenges for conservations and incentives for evolutionary studies in a gastropod species flock from Lake Tanganyika, J. Conchol., Special Publication, 3, 118, 2003.

Michel, E., Genner, M., and Todd, J.: Creeping invasive: the threat of an introduced Melanoides gastropod in Lake Malawi, Tentacle, 16, 6-7, 2008.

Ngereza, C.: Lavigeria grandis, in: IUCN 2011, IUCN Red List of Threatened Species, Version 2012.1, http://www.iucnredlist.org/, 2010.

Pain, T.: Molluscs, in: Preliminary Report on Some Fossils from the Chiwondo Beds of the Karonga District, Malawi, edited by: Coryndon, S., American Anthropologist, 68, 59-66, 1966.

Sandrock, O., Kullmer, O., Schrenk, F., Juwayeyi, Y., and Bromage, T.: Fauna, taphonomy, and ecology of the Plio-Pleistocene Chiwondo Beds, Northern Malawi, in: Hominin Environments in the East African Pliocene: an Assessment of the Faunal Evidence, edited by: Bobe, R., Alemseged, Z., and Behrensmeyer, A. K., Springer Verlag, Heidelberg, 315-332, 2007.

Schrenk, F., Bromage, T. G., Gorthner, A., and Sandrock, O.: Paleoecology of the Malawi Rift: vertebrate and invertebrate faunal contexts of the Chiwondo Beds, Lake Malawi, J. Hum. Evol., 28, 59-70, 1995.
Schultheiß, R., Van Bocxlaer, B., Wilke, T., and Albrecht, C.: Old fossils-young species: evolutionary history of an endemic gastropod assemblage in Lake Malawi, P. Roy. Soc. Lond. B-Bio., 276, 2837-2846, 2009.

Schultheiß, R., Wilke, T., Jørgensen, A., and Albrecht, C.: The birth of an endemic species flock: demographic history of the Bellamya group (Gastropoda, Viviparidae) in Lake Malawi, Biol. J. Linnean Soc., 102, 130-143, 2011.

Sengupta, M., Kristensen, T., Madsen, H., and Jørgensen, A.: Molecular phylogenetic investigations of the Viviparidae (Gastropoda: Caenogastropoda) in the lakes of the Rift Valley area of Africa, Mol. Phylogenet. Evol., 52, 797-805, 2009.

Tiercelin, J.-J., Schuster, M., Roche, H., Brugal, J. P., Thuo, P., Prat, S., Harmand, S., Davtian, G., Barrat, J.-A., and Bohn, M.: New considerations on the stratigraphy and environmental context of the oldest (2.34 Ma) Lokalalei archaeological site complex of the Nachukui Formation, West Turkana, northern Kenya Rift, J. Afr. Earth Sci., 58, 157-184, 2010.

Trauth, M. H., Maslin, M., Deino, M. A., Deino, A., and Strecker, M. R.: Late Cenozoic Moisture History of East Africa, Science, 203, 2051-2053, 2005.

Trauth, M. H., Maslin, M. A., Deino, A., Strecker, M. R., Bergner, A. G. N., and Dühnforth, M.: High- and low-latitude forcing of Plio-Pleistocene African climate and human evolution, J. Hum. Evol., 53, 475-486, 2007.

Trauth, M. H., Maslin, M. A., Deino, A., Junginger, A., Lesoloyia, M., Odada, E., Olago, D. O., Olaka, L., Strecker, M. R., and Tiedemann, R.: Human Evolution and Migration in a Variable Environment: The Amplifier Lakes of East Africa, Quat. Sci. Rev., 29, 2981-2988, 2010.

Van Bocxlaer, B.: Morfologische veranderingen in de malacofauna van het Malawimeer (Malawi) sinds het Midden-Holoceen, Master's Dissertation, Faculty of Sciences, Ghent University, 216 pp., 2004.

Van Bocxlaer, B.: Palaeobiology and evolution of the late Cenozoic freshwater molluscs of the East African Rift, Ph.D. Dissertation, Faculty of Sciences, Ghent University, 262 pp., 2010.

Van Bocxlaer, B. and Van Damme, D.: Illuminating the black box of punctuated equilibrium evolution: evolutionary punctuations in Bellamya gastropods from Lake Malawi. Abstract for oral presentation: Miscellanea Paleontologica, Liège, 4 December, 2009.

Van Bocxlaer, B., Van Damme, D., and Feibel, C. S.: Gradual versus punctuated equilibrium evolution in the Turkana Basin molluscs: Evolutionary events or Biological Invasions?, Evolution, 62, 511-520, 2008.

Van Bocxlaer, B., Salenbien, W., Praet, N., and Verniers, J.: Stratigraphy and paleoenvironments of the early to middle Holocene Chipalamawamba Beds (Malawi Basin, Africa), Biogeosciences, 9, 4497-4512, doi:10.5194/bg-9-4497-2012, 2012.

Van Damme, D.: Taxonomy, Ecology and Evolution of the Fossil Freshwater molluscs of the Turkana Basin (Ethiopia, Kenya), Ph.D. dissertation, Faculty of Sciences, Ghent University, 302 pp., 1976.

Van Damme, D.: The Freshwater Mollusca of Northern Africa, Distribution, Biogeography and Palaeoecology, Developments in Hydrobiology 25, Junk, The Hague, 1-162, 1984.

Van Damme, D.: Biogeography, palaeoecology en evolution of the North African freshwater molluscs during the Quaternary, D.Sc. dissertation, Faculty Exact Sciences, Gent University, 320 pp., 
1988.

Van Damme, D. and Pickford, M.: The Late Cenozoic Viviparidae (Mollusca, Gastropoda) of the Albertine Rift Valley (UgandaZaire), Hydrobiologia, 390, 171-217, 1999.

Van Damme, D. and Pickford, M.: The late Cenozoic Thiaridae (Mollusca, Gastropoda) of the Albertine Rift Valley (UgandaZaire), Hydrobiologia, 498, 1-83, 2003.

Van Damme, D. and Pickford, M.: The Late Cenozoic bivalves of the Albertine Basin (Uganda-Congo), Geo-Pal Uganda 2, ISSN 2076-5746, Uganda Museum, Kampala, 1-121, 2010.

Van Damme, D. and Van Bocxlaer, B.: Freshwater molluscs of the Nile Basin, past and present, in: The Nile. Origin, Environments, Limnology and Human Use, edited by: Dumont, H. J, Monographiae Biologicae, Springer Verlag, Dordrecht, 89, 585-630, 2009.
Von Gersdorff Sørensen, L., Sørensen, A., and Kristensen, T.: Molecular diversity and phylogenetic relationships of the gastropod genus Melanoides in Lake Malawi, Afr. Zool., 40, 179-191, 2005.

West, K., Cohen, A. S., and Baron, M.: Morphology and Behavior of Crabs and Gastropods from Lake Tanganyika, Africa: Implications for Lacustrine Predator-Prey Coevolution, Evolution, 45, 589-607, 1991.

Wilson A., Glaubrecht M., and Meyer, A.: Ancient lakes as evolutionary reservoirs: Evidence from the thalassoid gastropods of Lake Tanganyika, P. Roy. Soc. Lond. B, 271, 529-536, 2004.

Won, Y.-J., Sivasundar, A., Wang, Y., and Hey, J.: On the origin of Lake Malawi cichlid species: A population genetic analysis of divergence, P. Natl. Acad. Sci., 102, 6581-6586, 2005.

Won, Y.-J., Wang, Y., Sivasundar, A., Raincrow, J., and Hey, J.: Nuclear Gene Variation and Molecular Dating of the Cichlid Species Flock of Lake Malawi, Mol. Biol. Evol., 23, 828-837, 2006. 